\title{
Circumstances Precluding Wrongfulness in Russian and German Criminal Law
}

\author{
Olga Yakovleva, and Anton Shamne* \\ Volgograd State University, Department of Criminal Law, 400062, Prosp. Universitetsky, 100, Volgograd, Russia
}

\begin{abstract}
The article discusses some problematic issues with respect to such legal institution as the circumstances precluding wrongfulness. The author characterizes the nature of the circumstances, provides various definitions, respectively, various features underlying the allocation of these circumstances. The comparative legal analysis of these types of circumstances is given on the basis of the criminal code of the Russian Federation and Germany. The article suggests some refinement in the present Institute of circumstances, in particular, more precise regulation of the concepts of illicitness and culpability, as well as inclusion of the victim's consent to undergo harm in the list of circumstances.
\end{abstract}

\section{Introduction}

The circumstances precluding wrongfulness occupy a special place in the legal system as they are directly connected with the problems of justice, humanism and respect for the rights and freedoms in the field of justice.

In the modern period of social development, changes in different areas occur quite often, especially through the development of virtual space. In connection with this, the changes happen also in the nature of crimes, methods of commission, there appear new types of crime (all sorts of crimes in social networks), respectively, there expands the range of acts which can be qualified as non-criminal in certain circumstances.

These circumstances are enshrined in the criminal law: the current Russian Federation Criminal code provides six types of circumstances excluding crime (chapter 8, articles 37-42) [1]. Despite the final list of these circumstances, the flexible part includes the act itself qualified as non-criminal. In particular, in legal practice, it is often difficult to classify acts which are characterized by the presence of several circumstances excluding crime.

Circumstances precluding wrongfulness are sufficiently described in the scientific legal literature. However, law-enforcement practice in this area poses many questions to lawyers, which is evidenced by the number of works revealing the necessity of more detailed and extensive interpretation of these circumstances [2], [3].

\section{Approaches to defining the concept "circumstances wrongfulness"}

Some researchers believe that such a circumstance precluding wrongfulness as a necessary defense is not clearly and unambiguously defined in the criminal law [4]. In our view, in the law-enforcement practice it can be difficult to qualify the acts from the point of view of such a circumstance as a reasonable risk because it is often quite difficult to prove that "the above-mentioned goal could not be achieved through non-risky actions (or inaction)" (Russian Federation Criminal Code, article 41).

The scientific and legal literature, as a rule, presents similar definitions of circumstances precluding wrongfulness, individual authors give more general definitions, for example: "the circumstances precluding wrongfulness refer to such circumstances, the presence of which turns acts outwardly similar to the crimes into legitimate ones, and some of them even into socially useful" [5], [6]. Other authors present more detailed definitions: "the circumstance precluding wrongfulness is a conscious and willful action of a person associated with causing some harm to others, but because of the lack of social danger and their usefulness recognized by the criminal law it is justified as precluding wrongfulness, and hence the criminal liability of a person for harm brought" [7].

The circumstances precluding wrongfulness, as we have already pointed out, are lawfully enshrined in the current Russian Federation Criminal Code in chapter 8, there are 6 of these circumstances - each in a separate article: justifiable self-defence (article 37); causing injury to offender during detention (article 38); extreme urgency (article 39); physical or mental coercion (article 40); reasonable risk (article 41); carrying out an order or instruction (article 42).

* Corresponding author: antonsh97@gmail.com 


\section{The nature of the analyzed circumstances}

Scientists have different interpretations of the nature of the circumstances; in the theory of criminal law that nature was assessed differently: as circumstances precluding social danger, criminal liability and punishability, wrongfulness, and so on [8].

So far in the domestic law, the most famous and common theory is the one formed in the Soviet criminal law. From the point of view of this theory, wrongfulness is precluded as there is no such material basis as social dangerousness of the act; by the way, the harm caused by the act is regarded as "public and neutral" or even "socially useful" [9], [10].

In the late 90's- early 2000-ies there appear other views on the nature of the analyzed circumstances. In particular, in the works by V.A. Blinnikova the concept of "external factor", in this case we are talking about the absence of the sign of wrongfulness and not about a characteristic of social danger since the law provides the causes of admissibility of the damage caused [11]. As it is noted by S.G. Kelina, "in fact, the law provides an indefinite circle of persons with the right to harm the objects of criminal law protection in certain clearly limited situations: in cases of necessary defense, extreme necessity, reasonable risk, etc.; damage resulting from the implementation of this right shall not entail liability and punishment" [12].

Other scientists prioritize the social benefit of the act. S.V. Parkhomenko considers that the circumstances of this category preclude the liability in light of the social benefit of the acts committed under certain conditions stipulated by law [13].

Some authors note that the causes that contribute to precluding the acts from the criminal ones are of the complex character: the refusal of the state from criminal prosecution (preclusion of the wrongfulness) in this situation is associated with the absence of social danger of the act, as well as the possible lack of personal guilt in its perpetration [12].

We consider it expedient to characterize the Institute of the circumstances precluding wrongfulness from the standpoint of comparative legal analysis, comparing it with a similar institution in German legislation. This comparison is interesting because the German criminal law has a long tradition, the FRG Criminal Code Strafgesetzbuch (StGB) was enacted in 1871 and with some amendments, it exists up to the present time. The systems of criminal law in Russia and Germany have their own characteristics based on historical traditions and different crime theories. This mapping allows a deeper look at the specifics of the Russian Institute of the circumstances under consideration.

It is particularly noteworthy that German Institute of the circumstances precluding wrongfulness is regulated not only by StGB, but also by other normative acts including the Civil Code, as well as the theory of German criminal law (ungeschriebene Gründe - the socalled "unwritten reason") [14]. However, the consolidation of this Institute finds StGB in the fourth part (§ 32-35) [15].

\section{Identifying groups of circumstances}

Mapping the Russian Federation Criminal Code and StGB shows the difference in understanding how to consider the Institute in the criminal legislation of the countries. StGB provides a broader concept; the key here is not the concept of criminality/non-criminality of the acts and the wrongfulness/non-wrongfulness and punishability/impunity of acts. Accordingly, the authors singled out different circumstances precluding wrongfulness (and therefore criminality) of the act and circumstances precluding culpability (and, therefore, eliminating or mitigating the punishment): Rechtfertigungsgründe and Entschuldigungsgründe. Rechtfertigungsgründe literally means "causes of justification" ("justified" is referred by the component "Recht"), "the causes of purgation" [16]. Entschuldigungsgründe in the domestic legal literature is usually translated as "excusable circumstances" [14]. However, this translation is, in our opinion, not entirely accurate. "Entschuldigung" includes not only the concept "apology" but a wider one - "forgiveness" through the explanation of someone's behavior, the causes for mitigating guilt [16]. Therefore, in this case a more accurate translation would be "forgiving or justifying circumstances". So, based on the dictionary interpretation, we can offer a more accurate translation: Rechtfertigungsgründe include reasonably justifying circumstances and Entschuldigungsgründe - forgiving and justifying circumstances.

In the group of reasonably justifying circumstances (precluding wrongfulness of the act), the legislator includes the necessary self-defence ( $§ 32$ Notwehr) and reasonably justified extreme urgency (hereinafter, our translation) ( $\$ 34$ Rechtfertigender Notstand). The group of forgiving and justifying circumstances (excluding or mitigating culpability) includes the excess of necessary self-defence ( $\$ 33$ Überschreitung der Notwehr) and forgivably justified extreme urgency (§ 35 Entschuldigender Notstand) [15].

Let us dwell on the first group of circumstances precluding wrongfulness of the act. The paragraph 32 says: (1) Wer eine Tat begeht, die durch Notwehr geboten ist, handelt nicht rechtswidrig (the one who acted through the necessary self-defence has not acted illegally (i.e. unlawfully). Further, the legislator cites the definition of self-defence: (2) Notwehr ist die Verteidigung, die erforderlich ist, um einen gegenwärtigen rechtswidrigen Angriff von sich oder einem anderen abzuwenden - self-defence is protecting yourself or another person to prevent the current illegal (i.e. unlawful) attack. Thus, the legislator singles out such important issues as protection, the occurrence (i.e. reality) of the attacks, its wrongfulness. In the Russian Federation Criminal Code, this fact is described in more detail. Here the focus is primarily attracted to the caused harm and social danger of infringement: "It is not a crime to cause harm to an attacker in self-defence, i.e. when protecting the person and the rights of the defender or other persons, interests of the society or the state protected by the law from socially dangerous infringement if this infringement is associated with 
violence, life-threatening with respect to the defender or another person, or with direct threat of application of such violence" (article 37, part 1) [1]. Great importance is found in the nature and risk level of infringement (article 37, part 2). Part 3, article 37 is important as it indicates the circle of persons covered by the provisions of this article.

The second group of circumstances (excluding or mitigating culpability) in terms of the justifiable selfdefence concerns exceeding its limits: Überschreitet die Grenzen der Täter aus Verwirrung der Notwehr, Furcht oder Schrecken, so wird er nicht bestraft $(\$ 33)$ - the one who exceeds the limits of justifiable self-defence due to confusion, fear or fright cannot be punished. Thus, in this case we have listed the situations that allow exceeding the limits of self-defence and eliminating culpability. The Russian Federation Criminal Code also has articles about exceeding the limits of defence (article 108, article 114); in addition, paragraph 2.1 article 37 separately qualify the actions of the defender in a situation of surprise without considering it excessive: "The actions of the defender are not exceeding the limits of justifiable self-defence if that person due to the surprise assault could not objectively evaluate the extent and the nature and the danger of an attack" [1].

Reasonably justifying circumstances (precluding wrongfulness) related to the extreme urgency are presented, as we have already noted, in $\S 34$ and largely resemble article 39 of the Russian Federation Criminal Code. However, there is a more detailed interpretation of the circumstances presented in the StGB, in particular there is given a detailed enumeration of those benefits that are protected - life, body, freedom, honour, property, and also specified the need to comply with the level of danger to the interests ("balance of interests"). The Russian Federation Criminal Code says about the degree of harm and exceeding the limits of extreme urgency according to paragraph 2 article 39.

Differences in interpretation of extreme urgency in the criminal code of the countries under consideration are traced in $\S 35 \mathrm{StGB}$, which mentions the circumstances mitigating the culpability; we are talking about cases when the person has created a situation of danger or was in a particular legal relationship which involves the situation of danger (e.g., police), but taking into account the circumstances of extreme urgency, even if you have exceeded its limits, the punishment may be mitigated [17]; and StGB specifically stipulates that the danger must exist only to the life, health or freedom of the individual or of his family and friends and thus it is possible to prevent the danger only by committing a wrongful act. Such situations of extreme urgency are not regulated in the Russian Federation Criminal Code.

Special attention is given to the victim's consent to harm. In the Russian Federation Criminal Code it is not fixed, unlike the criminal code of Germany where $\S 228$ notes that is not considered illegal, i.e., unlawful act, when there exists the victim's consent to receive the injury, but only if it met the condition of following generally accepted moral standards. In our view, the regulation provided in the criminal code of Germany is rather vague because it does not ensure full understanding of the feasibility of such acts, moreover, it is unclear what is meant by the observance of morality [18].

Thus, the comparative analysis of general characteristics of the circumstances precluding wrongfulness in the StGB and Russian Federation Criminal Code showed the following. In contrast to the Russian criminal legislation, the German one divides circumstances into precluding the wrongfulness of an act and precluding culpability, which include the justifiable self-defence, extreme urgency and the victim's consent to harm. At the same time, more details are given to the circumstance of extreme urgency; but $n$ the Russian Federation Criminal Code self-defence is regulated in more details.

Perhaps some experience in German criminal law should be taken into account, in particular - we should pay attention to the clearer regulation of unlawfulness and culpability in the framework of the considered Institute of circumstances, and it will contribute to a more accurate assessment of the actions and to emerging opportunity to avoid more mistakes. And we should particularly comprehend the issue of a possible inclusion of such circumstance as the victim's consent to injury into the list of available circumstances in the Russian criminal legislation. However, this issue requires careful consideration in relation to such matters as validity and terms of implementation. We believe that in this case one should stipulate in detail the conditions, and especially it concerns such challenge as euthanasia. Perhaps from the point of view of the Russian people mentality, euthanasia is unacceptable, but in other cases (not so radical) the consent of the person to undergo harm can be justified in many ways [19], [20].

We would like to dwell on such circumstance as suppression of terrorist acts. In the present period, when terrorism has become a "daily occurrence", suppression becomes as relevant as ever. Despite the possibility of including it into extreme urgency, it has its own specifics. As usual, we talk about protecting the interests of large groups of people (and sometimes of the entire country), possible human sacrifice (so how to correlate then the prevented damage and the caused one?), the specific context in which the people act to prevent this harmful event; it is also very difficult to interpret exceeding / non-exceeding the limits of suppression in this case. In this regard, this circumstance might need to be allocated separately.

For other kinds of circumstances we would like to highlight the following. Self-defense involves primarily, as we have analyzed, protection of the defender's life [21-23]. However, it seems appropriate to consider the experience of foreign countries in this case and further regulate the possibility of justifiable self-defence to protect personal property. Indeed, the seizure of personal property may also be accompanied by its protection or self-defence (a human can sometimes have this as the only source of income, e.g. a car). Of course, it should be separately specified what kind of property it must be.

\section{Conclusion}


The criminal legislation of any country has its own peculiarity, which is largely due to the historical traditions and peculiarities of law development. Comparison of the circumstances precluding wrongfulness in the criminal legislation of Russia and Germany has shown different approaches to their allocation. The Russian legislation allocate them as the circumstances precluding criminality (i.e., wrongfulness), the German legislation - as the circumstances precluding the wrongfulness or liability to punishment. So respectively, the act here could be qualified either as lawful, unpunishable, or as unlawful but still unpunishable (here we are talking about commutation of sentence); in this case a more thorough classification of the nature of the acts is obvious. We have also offered clarification on providing in Russian legal literature a translation of some concepts from German into Russian within the framework of this Institute of circumstances [24-25].

Despite the regulation of the Institute of the circumstances precluding wrongfulness by the current Russian Federation Criminal Code, this field continues to cause many questions requiring further study. In particular, it is possible to allocate other kinds of circumstances, to provide a more detailed definition of existing circumstances, to clarify some concepts in relation to specific circumstances.

\section{References}

1. The Criminal Code of the Russian Federation dated 13.06.1996 No. 63-FZ (ed. 19.12.2016), URL: http://www.consultant.ru/document/cons_doc law $\underline{10699}$ (date of access: 16.03.18)

2. K.I. Popov, Legal science 3, 63-66 (2011)

3. M.A. Suzdalova, V.G. Lizunkov, E.Yu. Malushko, N.A. Sytina, V.E. Medvedev, The European Proceedings of Social \& Behavioural Sciences EpSBS XIX, 450-455 (2017)

4. A.T. Weltmander, Situation of the circumstance excluding criminality of the act: the theoretical basis and criminal and legal value: abst. dis. cand. of law sc. (Tomsk, 2013)

5. CH.I. Zaripova, TISBI Bulletin 4 (2007)

6. N. Davis, O. Ergunova, V. Lizunkov, E. Malushko, European Proceedings of Social and Behavioural Sciences 26, 550-556 (2017)

7. Criminal law of Russia. General part (Moscow: Volters Kluver, 2005)

8. A.A. Piontkovsky, Doctrine about a crime according to the Soviet criminal law. The course of the Soviet criminal law: General part, 410-416 (M.: Gosyurizdat, 1961)

9. I.I. Slutsky, Circumstances excluding criminal liability, 11-12 (L.: Publishing House LGU, 1956)

10. Criminal law of Russia. Practical course (M., 2007)

11. V.A. Blinnikov, Circumstances precluding wrongfulness in the criminal law of Russia, 25-31 (Stavropol: Stavropol state university, 2001)
12. S.G. Kelina, Criminal law 3, 5-7 (1999)

13. S.V. Parkhomenko, Acts, which criminality is excluded due to social usefulness and necessity: monograph, 99-118 (SPb.: Legal center-Press, 2004)

14. N.A. Lenchina, Circumstances, eliminating the illicitness of an act, in German criminal law: Abst. dis. cand. of law sc. (M., 2013)

15. Strafgesetzbuch, URL: http://www.gesetze-iminternet.de/stgb (date of access: 16.03.18).

16. Wahrig Gerhard Deutsches Wörterbuch. Jubiläumsausgabe, (Bertelsmann Lexikon Verlag, 1993)

17. V.D. Pakutin, Institute of circumstances precluding the criminality of an act in the law systems of some foreign states (comparative analysis), URL: http://kalinovsky-k.narod.ru/b/ufa20033/13.htm (date of access: 16.03.18)

18. E. Korobova, I. Kardovich, D. Mironova, M. Konysheva, Advances in Social Science Education and Humanities Research (ASSEHR) 97, 119-124 (2017)

19. L.N. Smirnova, Bulletin of the Tomsk state university: State and law. Legal sciences 308, 130133 (2008)

20. E.V. Murugova, Vestnik Volgogradskogo Gosudarstvennogo Universiteta-seriya 2yazykoznanie 16 (2), 197-200 (2017)

21. N.L. Shamne, E.V. Shishkina, Vestnik Volgogradskogo Gosudarstvennogo Universitetaseriya 2-yazykoznanie 16 (2), 143-151 (2017)

22. M.V. Konysheva, Materials of the International Scientific Conference on "Import substitution policy and development of non-resource export as the priority of today's industrial policy of Russian Federation. Conference proceedings", 159-167 (Plekhanov Russian University of Economics, Moscow, 2016)

23. G. Venturini, Netherlands Yearbook of International Law 41, 45-78 (2010)

24. Lee Jeong Ki, Jae-Jin Lee, Journal of Media Law, Ethics and Policy 14(2), 1-38 (2015)

25. Gon Yi In, Law Review 55, 285-312 (2014) 